Check for updates

Cite this: RSC Adv., 2019, 9, 27953

Received 1st June 2019

Accepted 2nd September 2019

DOI: $10.1039 / c 9 r a 04143 e$

rsc.li/rsc-advances

\section{A restricted access molecularly imprinted polymer coating on metal-organic frameworks for solid- phase extraction of ofloxacin and enrofloxacin from bovine serum $\uparrow$}

\author{
Zhian Sun, (D) Huachun Liu, Yanqiang Zhou, Shanwen Zhao, Jianmin Li, \\ Xiaoxiao Wang and Bolin Gong (D) *
}

\begin{abstract}
A restricted access molecularly imprinted polymer (RAMIP) crosslinked with bovine serum albumin (BSA) was prepared on the surface of the mesoporous $\mathrm{UiO}-66-\mathrm{NH}_{2}$ metal-organic framework (MOF). The surface morphology, imprinting behavior, and protein exclusion properties of UiO-66- $\mathrm{NH}_{2}$ @RAMIP@BSA were investigated. The maximum adsorption capacity was $50.55 \mathrm{mg} \mathrm{g}^{-1}$ for ofloxacin, with a $99.4 \%$ protein exclusion rate. Adsorption equilibrium was reached in 9 min. Combined with RP-HPLC, a solidphase extraction column filled with UiO-66- $\mathrm{NH}_{2}$ @RAMIP@BSA was used to selectively enrich and analyze ofloxacin and enrofloxacin antibiotics from bovine serum with recoveries of 93.7-104.2\% with relative standard deviations of $2.0-4.5 \%(n=3)$. The linear range and the limit of detection were $0.1-100$ $\mu \mathrm{g} \mathrm{mL} \mathrm{L}^{-1}$ and $15.6 \mathrm{ng} \mathrm{mL} \mathrm{L}^{-1}$, respectively. These results suggest that $\mathrm{UiO}-66-\mathrm{NH}_{2}$ (RAMIPaBSA is an efficient pretreatment adsorbent for biological sample analysis.
\end{abstract}

\section{Introduction}

Ofloxacin (OFL) and enrofloxacin (ENRO) are common fluoroquinolone antibiotics that are widely used because of their broad spectrum and good therapeutic effects. However, overuse has caused environmental pollution and bacterial resistance. There is thus an urgent need to a develop high-performance detection technology to monitor rational applications.

There are several established methods for OFL and ENRO analysis. Complex sample pretreatment is often necessary to remove interfering components (including biological macromolecules such as proteins), and to enrich the concentration of the target. Different strategies include protein precipitation, liquid-liquid extraction, solid-phase extraction, neutral salt solutions, organic solvents, and restricted-access media (RAM). Compared with other adsorbents, RAM can extract small molecules and exclude biological macromolecules, ${ }^{1}$ greatly simplifying sample pre-treatment, but it lacks target selectivity. However, molecularly imprinted polymers (MIPS) have very high selectivity for small molecules. In particular, surface imprinting overcomes the shortcomings of normal imprinting methods, ${ }^{2-4}$ with a large adsorption capacity and a fast mass transfer rate. Imprinted core materials play an important role in the

School of Chemistry and Chemical Engineering, North Minzu University, No. 204 Wenchang North Street, Xixia District, Yinchuan 750021, P. R. China. E-mail: gongbolin@163.com; Fax: +86-951-2067917; Tel: +86-951-2067917

$\dagger$ Electronic supplementary information (ESI) available. See DOI: 10.1039/c9ra04143e adsorption properties. For example, Lv et al. prepared florfenicol $\mathrm{Fe}_{3} \mathrm{O}_{4} @ \mathrm{RAMIP}$ (restricted access molecularly imprinted polymer) nanoparticles for the enrichment and separation of florfenicol from milk. ${ }^{5} \mathrm{Xu}$ et al. prepared sulfamethazine silica@RAMIP for on-line detection of sulfonamides in bovine milk. ${ }^{6}$ These matrices are traditional materials, and it is necessary to find new core materials to improve the enrichment performance.

Metal-organic frameworks (MOFs) are highly crystallized porous materials of self-assembling metal ions with organic ligands. ${ }^{7}$ The incorporation of MOFs in MIPs is beginning to attract great interest for separations. For example, MOF-5@MIPs for metolcarb has a higher specific surface area and a faster masstransfer rate relative to those of bulk MIPs. ${ }^{8}$ Nanocomposite MOF-5@MIPs for lipocalin greatly increased the analyte accessibility to the imprinted molecular cavities, ${ }^{9}$ while $\mathrm{Fe}_{3} \mathrm{O}_{4}$ nanoparticle HKUST-1@MIPs for gallic acid exhibited excellent extraction in real samples and a tunable porosity of HKUST- $1 .^{\mathbf{1 0}}$ Liu et al. synthesized dummy template MIL-101@MIPs to detect pyrraline in food samples, which exhibited fast mass-transfer rates and excellent selectivity. ${ }^{11}$ UiO-66 is a MOF that has good thermal stability, chemical inertness, ${ }^{12}$ a wide $\mathrm{pH}$ range (1-14), ${ }^{13}$ high pressure resistance, ${ }^{\mathbf{1 4}}$ and high mechanical strength. ${ }^{15}$ In particular, UiO-66- $\mathrm{NH}_{2}$ is easy to modify, and is thus an ideal imprinting composite material. However, its application in RAMIPs has not been reported.

Here, newly developed imprinted RAMIPs were synthesized using OFL as a template molecule, methacrylic acid as a functional monomer, trimethylolpropane trimethacrylate as a cross- 
linker, and glycidyl methacrylate as a hydrophilic monomer on the surface of UiO-66- $\mathrm{NH}_{2}$ in reversible addition-fragmentation chain transfer (RAFT) polymerization. To enhance the exclusion properties, and additional coating of cross-linked bovine serum albumin (BSA) was performed with an in-column process. The resulting RAMIPs was used to enrich OFL and ENRO from bovine serum samples.

\section{Experimental}

\subsection{Materials and apparatus}

$\mathrm{ZrCl}_{4}$ ( $\geq 99.9 \%$, metals basis), glycidyl methacrylate (GMA, $97 \%$ ), trimethylolpropane trimethacrylate (TRIM, GC, $>90.0 \%$ ), enrofloxacin (ENRO, 98\%), chloramphenicol (CAP, 98\%), sulfamerazine (SMZ, 99\%), amoxicillin (AMO, 98\%), methanol (HPLC, $\geq 99.9 \%$ ), acetonitrile (HPLC, $\geq 99.9 \%$ ), phosphoric acid (HPLC, 85-90\%), triethylamine (HPLC, $\geq 99.5 \%$ (GC)), sodium diethyldithiocarbamate trihydrate (analytical, 99.0\%), 2-chloroethyl isocyanate (97\%), bovine serum albumin (BSA), glutaraldehyde (AR, 50\%), sodium cyanoborohydride $\left(\mathrm{NaBH}_{3} \mathrm{CN}\right.$, 95\%), 2,2'-azobis(2-methylpropionitrile) (AIBN, 99\%) were all purchased from Aladdin Industrial Corporation, and AIBN was recrystallized with absolute ethanol. Methacrylic acid (MAA, 98\%) was bought from Aladdin Industrial Corporation, and was removed inhibitor in a column with neutral aluminum oxide. 2Aminoterephthalic acid ( $\geq 98 \%$ ) was obtained from Shanghai D\&B Biological Science and Technology Co. Ltd. Ofloxacin (OFL, 98.5\%) were bought from Tianjin Sima Technology Co., Ltd. Other reagents were analytical reagents.

The instruments that were used were a LC-20AT high performance liquid chromatography (HPLC) (Shimadzu, Japan), a SmartLab SE X-ray diffractometer (XRD) (Rigaku, Japan), a HT7700 transmission electron microscope (TEM) (Hitachi, Japan), FTIR-650 a Fourier transform infrared spectrometer (Gangdong, China), a SETARAM SETSYS16 thermogravimetric analyzer (TGA) (SETARAM, France), a ASAP 2020 HD88 surface area and porosity analyzer (Micromeritics, U.S.A), a Vario EL cube elemental analyzer (Elementar, Germany), and a UV2800S UVvisible spectrophotometer (Sunny Hengping, China).

\subsection{Synthesis}

2.2.1. Synthesis of UiO-66- $\mathrm{NH}_{2}$. The synthetic protocol of UiO-66- $\mathrm{NH}_{2} @$ RAMIP@BSA composites is shown in Fig. 1. UiO$66-\mathrm{NH}_{2}$ was synthesized according previous reports, with minor modifications. ${ }^{16} \mathrm{ZrCl}_{4}(5.0 \mathrm{mmol})$ and 2-aminoterephthalic acid (5.0 mmol) were dissolved in a $35 \mathrm{~mL}$ water/dimethylformamide (DMF) $(5 / 30, v / v)$ solution. The mixed solution was placed in a $100 \mathrm{~mL}$ autoclave and heated to $120{ }^{\circ} \mathrm{C}$ for $24 \mathrm{~h}$. The product was separated via centrifugation (5000 rpm, $15 \mathrm{~min}$ ) and rinsed several times with DMF. The product was then solventexchanged for $24 \mathrm{~h}$ with $30 \mathrm{~mL}$ chloroform; this process was repeated twice. Finally, the product was dried under vacuum at $100{ }^{\circ} \mathrm{C}$ for $24 \mathrm{~h}$.

2.2.2. Preparation of RAFT (reversible addition-fragmentation chain transfer) initiator. The UiO-66- $\mathrm{NH}_{2}(1.0 \mathrm{~g})$ and 2chloroethyl isocyanate $(0.3 \mathrm{~mL})$ were dissolved in anhydrous
$10 \mathrm{~mL}$ of dimethylsulfoxide (DMSO) and dispersed with ultrasound for $10 \mathrm{~min}$. The reaction was performed at $60^{\circ} \mathrm{C}$ for $24 \mathrm{~h}$. The product was then washed several times with DMSO to remove unreacted 2-chloroethyl isocyanate. The UiO-66$\mathrm{NH}_{2}$ @Cl product was then vacuum dried for $24 \mathrm{~h}$ at $60{ }^{\circ} \mathrm{C}$. Subsequently, UiO-66- $\mathrm{NH}_{2}$ @Cl (1.0 g) and sodium diethyldithiocarbamate trihydrate $(1.0 \mathrm{~g})$ were dispersed in $20 \mathrm{~mL}$ anhydrous tetrahydrofuran (THF). After purging the mixture with $\mathrm{N}_{2}$ for $20 \mathrm{~min}$, the reaction was performed at $55^{\circ} \mathrm{C}$ for $24 \mathrm{~h}$. The product was sequentially washed with THF, methanol/ water $(60 / 40, \mathrm{v} / \mathrm{v})$, and acetone. Finally, the UiO-66- $\mathrm{NH}_{2} @ S S$ product was dried in a $60{ }^{\circ} \mathrm{C}$ vacuum oven.

2.2.3. Preparation of UiO-66- $\mathrm{NH}_{2}$ @RAMIP@BSA. OFL $(0.25$ mmol), MAA (1 mmol) and TRIM (1 mmol) were dissolved in a $25 \mathrm{~mL}$ methanol/acetonitrile $(1 / 1, \mathrm{v} / \mathrm{v})$ solution, sonicated for $5 \mathrm{~min}$, and kept at $25^{\circ} \mathrm{C}$ for $2 \mathrm{~h}$. UiO-66- $\mathrm{NH}_{2} @ S S$ (1.0 g), GMA (2 $\mathrm{mmol}$ ), AIBN (35 mg) were then added to the mixed solution, purged with nitrogen for $20 \mathrm{~min}$, and reacted for $24 \mathrm{~h}$ at $60^{\circ} \mathrm{C}$. The product was dried at $60{ }^{\circ} \mathrm{C}$ after being washed with methanol. The polymers were Soxhlet extracted with methanol/acetic acid $(9 / 1, v / v)$ until there was no OFL in the extracting solution. The extracted UiO-66- $\mathrm{NH}_{2}$ @MIP was dispersed in $10 \mathrm{~mL}$ of sulfuric acid solution $\left(0.1 \mathrm{~mol} \mathrm{~L}^{-1}\right)$ for $10 \mathrm{~h}$ at $60^{\circ} \mathrm{C}$, after which the sulfuric acid was washed off the polymer surface. The resulting hydrolysate (UiO-66- $\mathrm{NH}_{2} @$ QRAMIP) was packed into the SPE column, and the vacuum of the SPE device was adjusted to keep the mixed solution [THF/acetonitrile/0.1 $\mathrm{mol} \mathrm{L}^{-1}$ $\mathrm{Na}_{2} \mathrm{HPO}_{4}-\mathrm{NaH}_{2} \mathrm{PO}_{4}$ buffer (pH 7.0), (1/9/90, v/v)] flowing

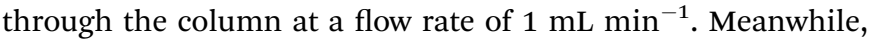
$12.5 \mathrm{~mL}$ of a $5.0 \mathrm{mg} \mathrm{mL} \mathrm{mL}^{-1}$ BSA aqueous solution was added slowly. Then, $50 \mathrm{~mL}$ of a $5 \%$ glutaraldehyde aqueous solution was added (keeping the $2 \mathrm{~mL} \mathrm{~min}^{-1}$ outflow rate). The UiO-66$\mathrm{NH}_{2}$ @RAMIP was incubated at $25^{\circ} \mathrm{C}$ for $2 \mathrm{~h}$ and then balanced with $2 \mathrm{~mL} \min ^{-1} \mathrm{NaBH}_{3} \mathrm{CN}$ solution $\left(50 \mathrm{~mL}, 0.3 \mathrm{~mol} \mathrm{~L}^{-1}\right)$. The cross-linking reaction lasted $2 \mathrm{~h}$ at $25{ }^{\circ} \mathrm{C}$, and then the column was washed with water and methanol sequentially. The final UiO-66- $\mathrm{NH}_{2} @ \mathrm{RAMIP@BSA} \mathrm{nanoparticles} \mathrm{were} \mathrm{vacuum} \mathrm{dried} \mathrm{at}$ $25{ }^{\circ} \mathrm{C}$.

The preparation of non-imprinted polymers (UiO-66$\mathrm{NH}_{2}$ @RANIP@BSA) was the same as those of the imprinted UiO-66- $\mathrm{NH}_{2} @ R A M I P @ B S A$, except no template molecules were added.

\subsection{Evaluation of protein exclusion efficiency}

The protein exclusion efficiency of the UiO-66- $\mathrm{NH}_{2}$ @RAMIP@BSA was assessed by the recoveries of BSA. A SPE column filled with UiO-66- $\mathrm{NH}_{2} @$ RAMIP@BSA was activated with methanol $(2 \mathrm{~mL})$ and triply-distilled water $(2 \mathrm{~mL})$, successively. The BSA aqueous solution $\left(1.0 \mathrm{mg} \mathrm{mL}^{-1}\right)$ was flowed through the column, and the solution absorbance at $280 \mathrm{~nm}$ was measured. The adsorption capacity was calculated with eqn (1):

$$
Q=\left(C_{0}-C_{\mathrm{e}}\right) V / m
$$

where $C_{0}\left(\mathrm{mg} \mathrm{L}^{-1}\right)$ was the initial concentration of BSA, $C_{\mathrm{e}}(\mathrm{mg}$ $\left.\mathrm{L}^{-1}\right)$ was the concentration after absorption, $Q\left(\mathrm{mg} \mathrm{g}^{-1}\right)$ was the 


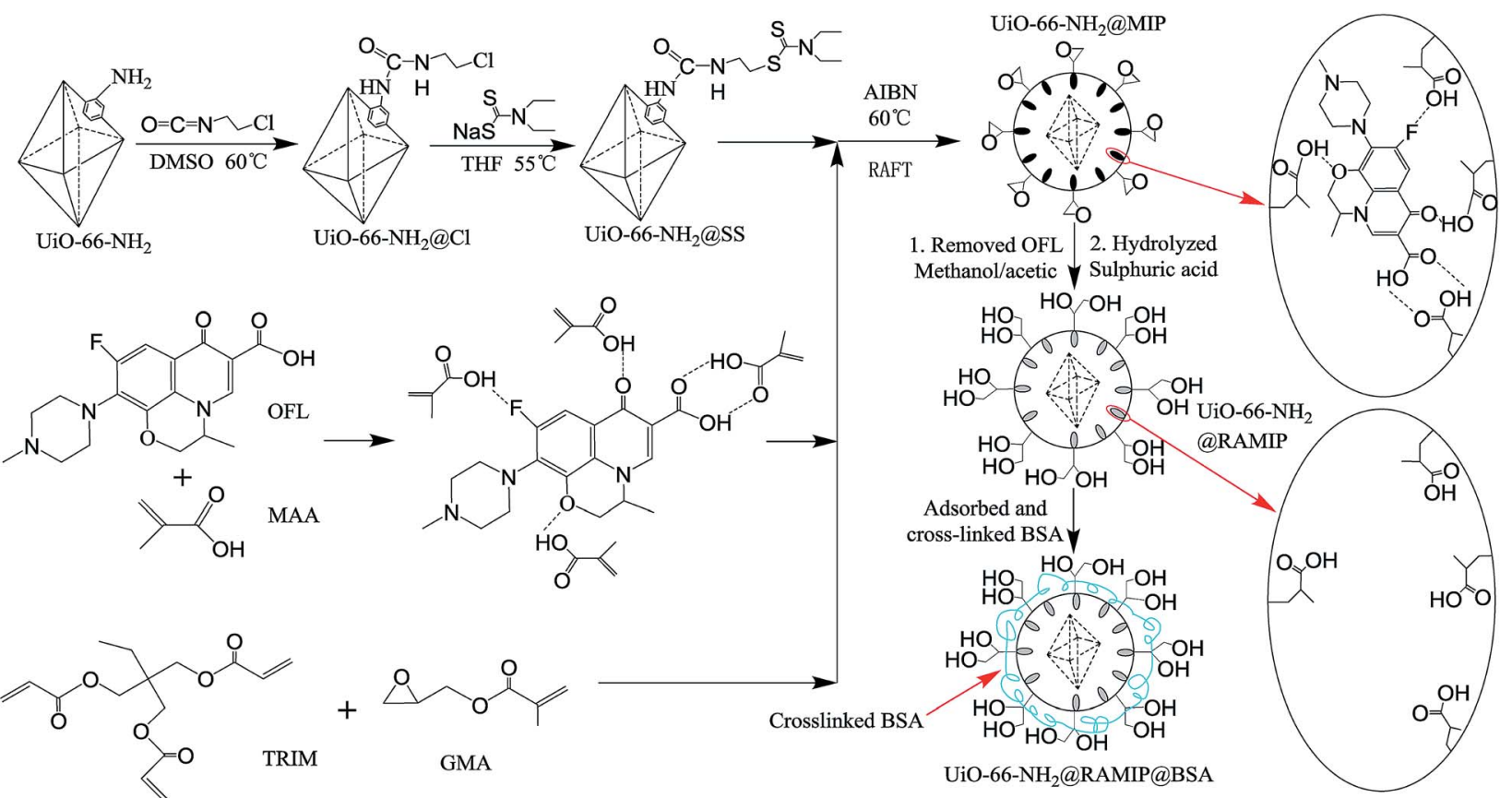

Fig. 1 Preparation procedures of $\mathrm{UiO}-66-\mathrm{NH}_{2}$ (aRAMIP@BSA.

adsorption capacity, $V(\mathrm{~L})$ was the solution volume, and $m(\mathrm{~g})$ was the mass of UiO-66- $\mathrm{NH}_{2} @ R A M I P @ B S A$ or UiO-66$\mathrm{NH}_{2} @ R A N I P @ B S A$.

The above procedure was the same for UiO-66- $\mathrm{NH}_{2} @-$ RANIP@BSA, UiO-66- $\mathrm{NH}_{2} @ R A M I P$, UiO-66- $\mathrm{NH}_{2} @ R A N I P$, UiO66- $\mathrm{NH}_{2} @ \mathrm{MIP}$, and UiO-66- $\mathrm{NH}_{2} @ \mathrm{NIP}$.

\subsection{Adsorption experiments}

The saturated adsorption capacity of UiO-66- $\mathrm{NH}_{2} @-$ RAMIP@BSA was examined with isothermal adsorption experiments. The UiO-66- $\mathrm{NH}_{2} @$ RAMIP@BSA $(0.0200 \mathrm{~g})$ was added to $2 \mathrm{~mL}$ of various OFL solutions in methanol with concentrations ranging over $100-1300 \mathrm{mg} \mathrm{L}^{-1}$. The adsorption process lasted for $12 \mathrm{~h}$ at $25{ }^{\circ} \mathrm{C}$ under oscillating conditions. The absorbance of the supernatant was measured, and the adsorption capacity was calculated from eqn (1).
The adsorption model was determined by fitting the isothermal adsorption data to Langmuir, Freundlich, and Langmuir-Freundlich models. The equations are as follows:

Langmuir equation:

$$
C_{\mathrm{e}} / Q_{\mathrm{e}}=C_{\mathrm{e}} / Q_{\mathrm{m}}+1 /\left(K_{\mathrm{L}} Q_{\mathrm{m}}\right)
$$

Freundlich equation:

$$
\ln Q_{\mathrm{e}}=(1 / n) \ln C_{\mathrm{e}}+\ln K_{\mathrm{F}}
$$

Langmuir-Freundlich equation:

$$
Q_{\mathrm{e}}=Q_{\mathrm{m}} K_{\mathrm{L}}{ }^{m} C_{\mathrm{e}}^{m} /\left(1+K_{\mathrm{L}}{ }^{m} C_{\mathrm{e}}^{m}\right)
$$

$C_{\mathrm{e}}\left(\mathrm{mg} \mathrm{L}^{-1}\right)$ was the equilibrium concentration of OFL, $Q_{\mathrm{e}}(\mathrm{mg}$ $\left.\mathrm{L}^{-1}\right)$ was the equilibrium adsorption capacity, $Q_{\mathrm{m}}\left(\mathrm{mg} \mathrm{g}^{-1}\right)$ was the saturated adsorption capacity, $K_{\mathrm{L}}\left(\mathrm{L} \mathrm{mg}^{-1}\right)$ is the Langmuir constant, $K_{\mathrm{F}}$ and $n$ are constants related to adsorption capacity

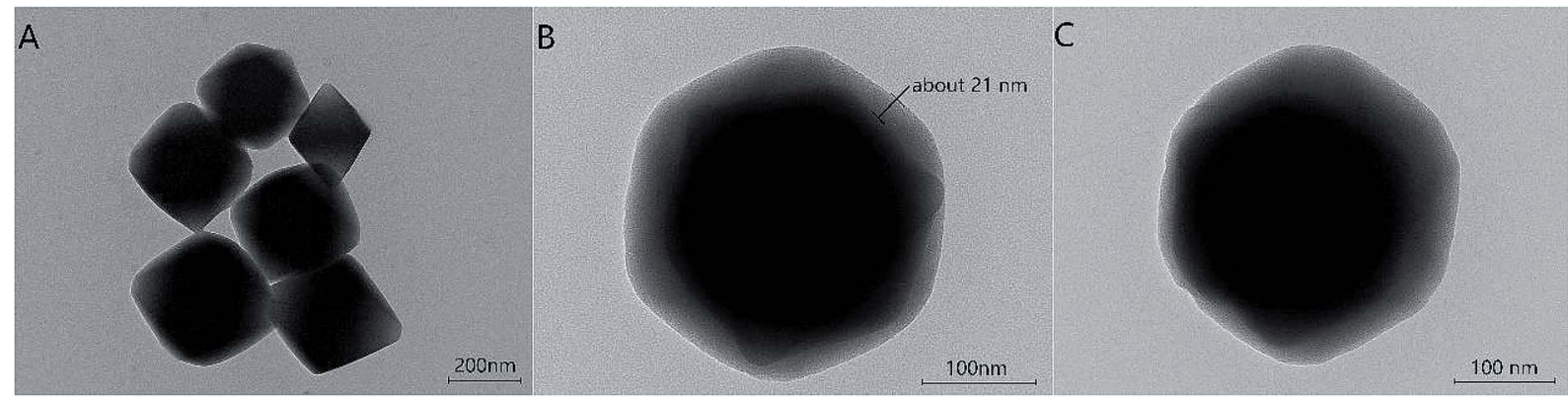

Fig. 2 TEM images of (A) UiO-66- $\mathrm{NH}_{2}$ (B) UiO-66- $\mathrm{NH}_{2}$ @RAMIP@BSA, and (C) UiO-66- $\mathrm{NH}_{2} @$ $(\mathrm{RANIP} @ \mathrm{BSA}$. 


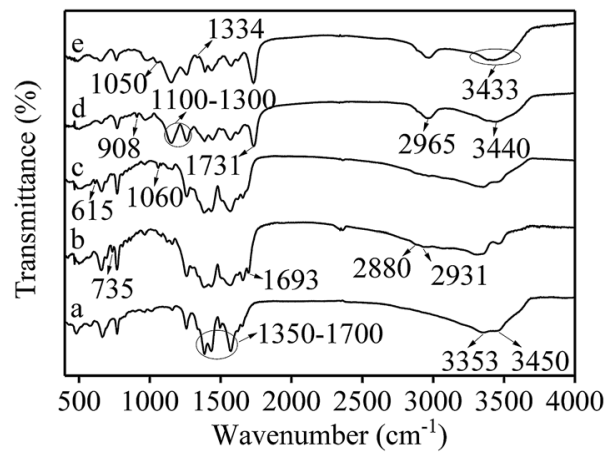

Fig. 3 FTIR spectra of (a) $\mathrm{UiO}-66-\mathrm{NH}_{2}$, (b) $\mathrm{UiO}-66-\mathrm{NH}_{2} \mathrm{aCl}$ (c) $\mathrm{UiO}-$ 66- $\mathrm{NH}_{2} @ \mathrm{aSS}$, (d) UiO-66- $\mathrm{NH}_{2}$ @MIP and (e) UiO-66- $\mathrm{NH}_{2}$ @RAMIP.

Table 1 Elemental analysis results of UiO-66- $\mathrm{NH}_{2} @$ RAMIP@BSA and UiO-66- $\mathrm{NH}_{2}$ @RAMIP

\begin{tabular}{lcccc}
\hline Materials & $\mathrm{N} \%$ & $\mathrm{C} \%$ & $\mathrm{H} \%$ & $\mathrm{O} \%$ \\
\hline UiO-66- $\mathrm{NH}_{2} @ R A M I P @ B S A$ & 6.33 & 41.40 & 5.85 & 24.78 \\
UiO-66- $\mathrm{NH}_{2} @ R A M I P$ & 4.92 & 39.95 & 5.72 & 24.85 \\
\hline
\end{tabular}

and adsorption strength, respectively, and $m$ was a constant to characterize the surface inhomogeneity.

The adsorption rate was determined by kinetics experiments at $25^{\circ} \mathrm{C}$. UiO-66- $\mathrm{NH}_{2} @$ RAMIP@BSA $(0.1000 \mathrm{~g})$ was dispersed in an $\mathrm{OFL} / \mathrm{methanol}$ solution $\left(1200 \mathrm{mg} \mathrm{L}^{-1}, 10 \mathrm{~mL}\right)$. The absorbance of the supernatant was measured every $1 \mathrm{~min}$ and the adsorption capacity was calculated from eqn (1).

The reaction order was determined by fitting the kinetics with the following model equations:

Pseudo first-order kinetic model:

$$
\ln \left(Q_{\mathrm{e}}-Q_{\mathrm{t}}\right)=\ln Q_{\mathrm{e}}-k_{1} t
$$

Pseudo second-order kinetic model:

$$
t / Q_{\mathrm{t}}=1 /\left(k_{2} Q_{\mathrm{e}}{ }^{2}\right)+t / Q_{\mathrm{e}}
$$

$Q_{\mathrm{e}}\left(\mathrm{mg} \mathrm{g}^{-1}\right)$ was the equilibrium adsorption capacity, $Q_{\mathrm{t}}(\mathrm{mg}$ $\mathrm{g}^{-1}$ ) was the $t(\mathrm{~min})$ to adsorption capacity, $k_{1}\left(\mathrm{~s}^{-1}\right)$ and $k_{2}(\mathrm{~g}$ $\mathrm{mg}^{-1} \mathrm{~s}^{-1}$ ) were the pseudo first-order and pseudo second-order rate constants, respectively.

The procedures were the same for UiO-66$\mathrm{NH}_{2} @ R A N I P @ B S A$.

\subsection{Adsorption selectivity}

UiO-66-NH $\mathrm{NH}_{2} @ R A M I P @ B S A(0.0200 \mathrm{~g})$ was added to a $2 \mathrm{~mL} \mathrm{CAP/}$ methanol solution $\left(1200 \mathrm{mg} \mathrm{L}^{-1}\right)$. The adsorption process lasted for $12 \mathrm{~h}$ at $25{ }^{\circ} \mathrm{C}$ under oscillating conditions. The adsorption capacity was calculated from eqn (1). The adsorption capacities of UiO-66- $\mathrm{NH}_{2} @$ @AMIP@BSA for ENRO, AMO, and SMZ were measured using the same procedure. The procedures were the same for UiO-66- $\mathrm{NH}_{2} @$ RANIP@BSA.

The UiO-66- $\mathrm{NH}_{2} @$ RAMIP@BSA selectivity was characterized by the imprinting factor IF and the selectivity coefficient SC.

$$
\mathrm{IF}=Q_{\mathrm{UiO}-66-\mathrm{NH}_{2} @ \mathrm{RAMIP} @ \mathrm{BSA}} / Q_{\mathrm{UiO}-66-\mathrm{NH}_{2} @ \mathrm{RANIP} @ \mathrm{BSA}}
$$

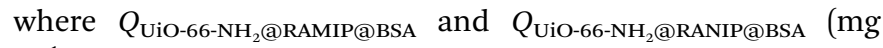
$\mathrm{g}^{-1}$ ) were the adsorption capacities of UiO-66- $\mathrm{NH}_{2}$ @RAMIP@BSA and UiO-66- $\mathrm{NH}_{2} @ R A N I P @ B S A$, respectively, for the target molecules.

$$
\mathrm{SC}=Q_{\mathrm{OFL}} / Q_{\mathrm{CM}}
$$

where $Q_{\mathrm{OFL}}$ and $Q_{\mathrm{CM}}\left(\mathrm{mg}^{-1}\right)$ were the UiO-66- $\mathrm{NH}_{2} @$ RAMIP@BSA adsorption capacities for OFL and competing molecules (ENRO, AMO, SMZ and CAP), respectively.

\subsection{Spiked recovery experiments and analysis of real samples}

OFL and ENRO methanol/water (1/1, v/v) standard solutions (500 $\mathrm{mg} \mathrm{L}^{-1}$ ) were prepared. To three $100 \mathrm{~mL}$ volumetric flasks were added $0.1 \mathrm{~mL}, 1.0 \mathrm{~mL}$, and $10 \mathrm{~mL}$ of the OFL standard solution, and each was diluted with bovine serum to the calibration line. A SPE column filled with UiO-66- $\mathrm{NH}_{2}$ @RAMIP@BSA or UiO-66- $\mathrm{NH}_{2} @ R A N I P @ B S A$ was activated with methanol $(2 \mathrm{~mL})$ and triply-distilled water $(2 \mathrm{~mL})$, successively. Without pretreatment, the bovine serum samples $(10 \mathrm{~mL})$ were injected directly into the SPE column, then the column was washed with $3 \mathrm{~mL}$ of water. The OFL and ENRO was eluted with a $3 \mathrm{~mL}$ mixture of methanol/acetic acid $(9 / 1, \mathrm{v} / \mathrm{v})$. The eluent was
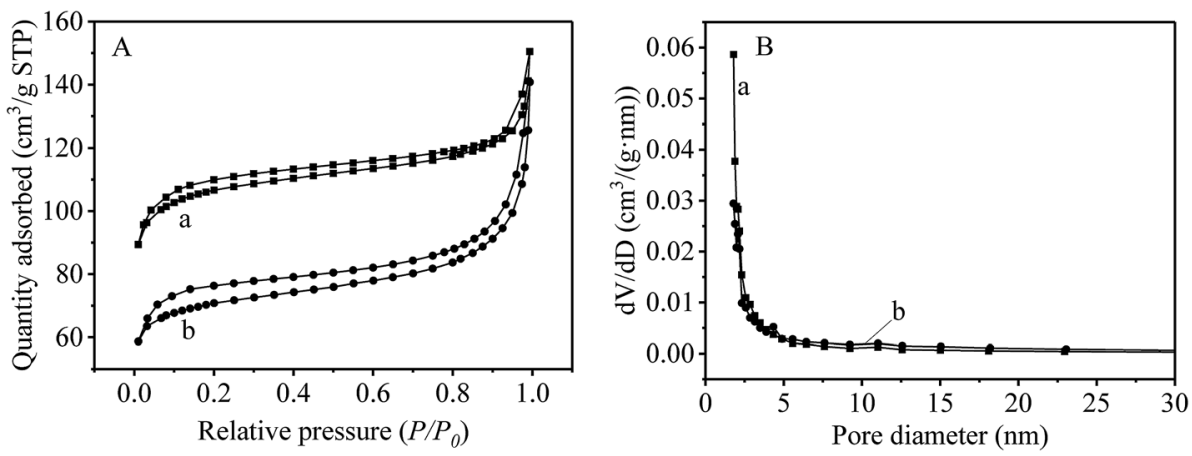

Fig. 4 (A) The specific surface area and (B) the pore size distribution (a) UiO-66- $\mathrm{NH}_{2}$ and (b) UiO-66-NH 2 (aRAMIP@BSA. 
Table 2 Protein exclusion rate of UiO-66-NH 2 @MIP, UiO-66- $\mathrm{NH}_{2} @ \mathrm{aNIP}, \mathrm{UiO}-66-\mathrm{NH}_{2} @ \mathrm{aRAMIP}, \mathrm{UiO}-66-\mathrm{NH} \mathrm{H}_{2} @ \mathrm{RANIP}, \mathrm{UiO}-66-\mathrm{NH} \mathrm{H}_{2} \mathrm{a}-$ RAMIP@BSA and UiO-66- $\mathrm{NH}_{2}$ @RANIP@BSA

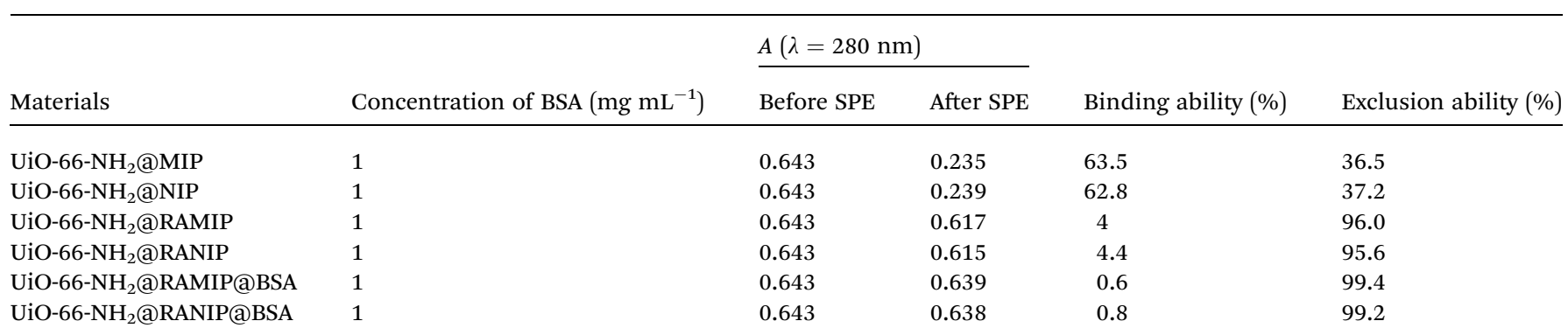

dried with nitrogen and dissolved again with $0.1 \mathrm{~mL}$ of the mobile phase. Samples $(15 \mu \mathrm{L})$ were taken for detection. The chromatographic conditions were: C18 column $(250 \mathrm{~mm} \times 4.6$ $\mathrm{mm}, 5 \mu \mathrm{m}$, Shimadzu); a mobile phase of $0.025 \mathrm{~mol} \mathrm{~L}^{-1}$ phosphoric acid aqueous solution $(\mathrm{pH}$ adjusted to 3 with triethylamine)/acetonitrile $=85 / 15(\mathrm{v} / \mathrm{v})$; a flow rate of 1 $\mathrm{mL} \min ^{-1}$; a column temperature of $40{ }^{\circ} \mathrm{C}$; and a UV detection wavelength of $286 \mathrm{~nm}$.

\section{Results and discussion}

\subsection{Synthesis of ofloxacin-imprinted UiO-66- $\mathrm{NH}_{2} @ R A M I P @ B S A$}

The synthesis of UiO-66- $\mathrm{NH}_{2} @ \mathrm{RAMIP@BSA} \mathrm{nanoparticles} \mathrm{is}$ illustrated in Fig. 1. The mesoporous UiO-66- $\mathrm{NH}_{2}$ substrate had excellent thermal stability, chemical inertness, stable physical and chemical properties, and a high adsorption capacity. The MIP layer was coated on the UiO-66- $\mathrm{NH}_{2}$ surface via RAFT. The first step was to prepare the initiator-functionalized UiO-66- $\mathrm{NH}_{2}$ (UiO-66- $\mathrm{NH}_{2} @ S S$ ). In the second step, the functional monomer MAA provided hydrogen bonding with the OFL template, TRIM was the cross-linking reagent used to form the polymer network, and GMA was used to form the first hydrophilic layer. The MIP layer easily grew from the initiator according to the RAFT mechanism. After Soxhlet extraction, the surface cavities could selectively rebind template molecules because they matched in shape, size, and chemical functional groups. After undergoing hydrolysis, the UiO-66- $\mathrm{NH}_{2} @$ RAMIP surface was covered with hydroxyl groups to prevent irreversible protein adsorption. Theoretically, the proportions of template molecule, functional monomer, crosslinking agent, and hydrophilic monomer could affect the adsorption performance. Hence, the ratios of OFL to MAA, MAA to TRIM, and TRIM to GAM were all optimized. The experimental range was $1: 4$, between $1: 0.6$ to $1: 1.6$, and between $1: 1.5$ to $1: 3$, respectively. Finally, crosslinking BSA was immobilized on the UiO-66- $\mathrm{NH}_{2}$ @RAMIP surface to form a second hydrophilic layer to enhance the protein exclusion efficiency.

\subsection{Characterization of ofloxacin-imprinted UiO-66- $\mathbf{N H}_{2} @ R A M I P @ B S A$}

The morphologies of UiO-66- $\mathrm{NH}_{2}$, UiO-66- $\mathrm{NH}_{2} @ R A M I P @ B S A$, and UiO-66- $\mathrm{NH}_{2} @$ RANIP@BSA were imaged with TEM. As shown in Fig. 2A, UiO-66- $\mathrm{NH}_{2}$ was an octahedral crystal with a smooth surface. UiO-66- $\mathrm{NH}_{2} @ \mathrm{RAMIP@BSA} \mathrm{nanoparticles}$ were evenly encapsulated by the $21.2 \mathrm{~nm}$-thick polymer, suggesting that the RAMIP layer were successfully coated on the UiO-66- $\mathrm{NH}_{2}$ surface. In addition, the thick and uniform imprinting layer could accelerate the mass-transfer rate and provide more adsorption sites. Fig. $2 \mathrm{~B}$ and $\mathrm{C}$ indicates that the surface morphology of UiO-66- $\mathrm{NH}_{2}$ @RANIP@BSA was similar to that of UiO-66- $\mathrm{NH}_{2} @ \mathrm{RAMIP} @ B S A$.

The preparation of the adsorbent was also confirmed with FTIR spectra (Fig. 3) and an elemental analysis (Table 1). In Fig. 3, the broad band at $1350-1700 \mathrm{~cm}^{-1}$ could be assigned to the $\mathrm{COO}^{-}$symmetrical and asymmetrical stretching vibration of UiO-66- $\mathrm{NH}_{2}$ in the five spectra (Fig. 3a-e). The $3353 \mathrm{~cm}^{-1}$ and $3450 \mathrm{~cm}^{-1}$ peaks in Fig. 3a were attributed to a $\mathrm{N}-\mathrm{H}$ vibration
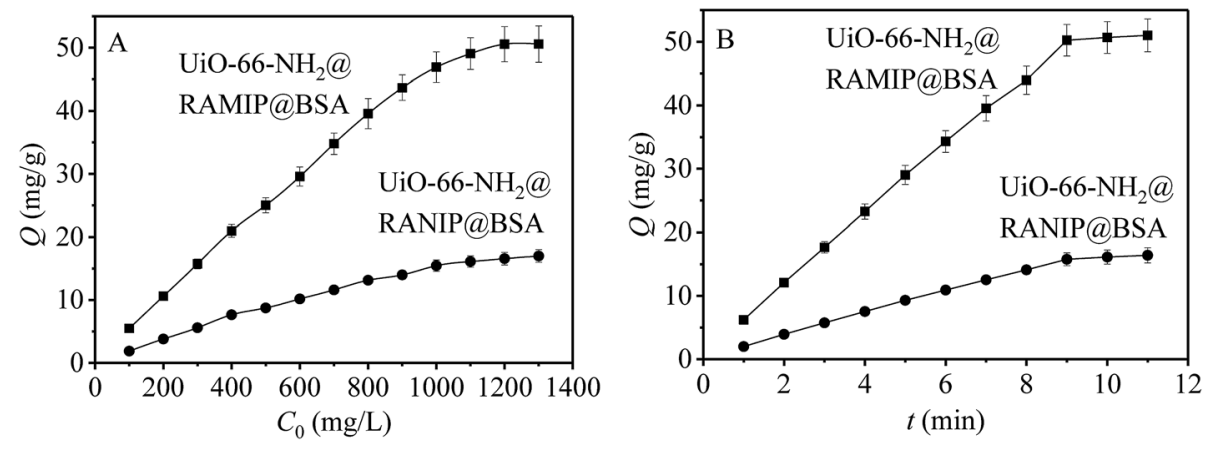

Fig. 5 Results of (A) absorption capacity and (B) absorption kinetics. 
from UiO-66- $\mathrm{NH}_{2}$. Comparing the a and b spectra, the absorption peaks of $\mathrm{C}-\mathrm{Cl}\left(735 \mathrm{~cm}^{-1}\right), \mathrm{C}=\mathrm{O}\left(1693 \mathrm{~cm}^{-1}\right.$, redshifted by two associated $\mathrm{N}-\mathrm{H}$ bonds), $\mathrm{CH}_{2}\left(2880 \mathrm{~cm}^{-1}\right)$ and $\mathrm{CH}_{3}$ $\left(2931 \mathrm{~cm}^{-1}\right)$ appeared in curve Fig. $3 \mathrm{~b}$, which verified that 2chloroethyl isocyanate was grafted on the UiO-66- $\mathrm{NH}_{2}$ surface. In Fig. 3c, $\mathrm{C}-\mathrm{S}$ and $\mathrm{C}=\mathrm{S}$ peaks appeared at $615 \mathrm{~cm}^{-1}$ and $1060 \mathrm{~cm}^{-1}$, respectively, verifying the grafting of sodium diethyldithiocarbamate trihydrate. In Fig. $3 \mathrm{~d}$, the $\mathrm{C}=\mathrm{O}$ overtone peak from esters occurred at $3440 \mathrm{~cm}^{-1}$. The symmetrical and asymmetrical C-H stretching vibration $\left(2965 \mathrm{~cm}^{-1}\right)$ and the ester carbonyl group stretching vibration $\left(1731 \mathrm{~cm}^{-1}\right)$ were significantly enhanced. Two strong $\mathrm{C}-\mathrm{O}-\mathrm{C}$ peaks appeared between $1100-1300 \mathrm{~cm}^{-1}$, and the epoxy group absorption peak appeared at $908 \mathrm{~cm}^{-1}$. All of these data indicated that MAA, TRIM, and GMA were grafted onto the surface of UiO-66$\mathrm{NH}_{2}$ @SS. In Fig. 3e, the $\mathrm{C}-\mathrm{O}$ stretching vibration and the $\mathrm{O}-\mathrm{H}$ deformation vibration occurred at $1050 \mathrm{~cm}^{-1}$ and $1334 \mathrm{~cm}^{-1}$, respectively. Thus, the peak at $3400 \mathrm{~cm}^{-1}$ was an $\mathrm{OH}$ band, which verified the hydrolysis of the epoxy group.

The amount of BSA bonding could be determined by the elemental analysis (Table 1). The N, C, and H content in UiO-66$\mathrm{NH}_{2} @$ RAMIP@BSA increased, which indicated that BSA had been cross-linked on the UiO-66- $\mathrm{NH}_{2} @$ RAMIP surface.

The specific surface areas of UiO-66- $\mathrm{NH}_{2}$ and UiO-66$\mathrm{NH}_{2} @$ RAMIP@BSA were determined by BET (Fig. 4A) to be $332.6 \mathrm{~m}^{2} \mathrm{~g}^{-1}$ and $210.4 \mathrm{~m}^{2} \mathrm{~g}^{-1}$, respectively. These were much higher than other MIPs, ${ }^{17,18}$ which was the basis for the increase of adsorption capacity. Furthermore, as shown in Fig. 4B, UiO66- $\mathrm{NH}_{2}$ and UiO-66- $\mathrm{NH}_{2} @$ (RAMIP@BSA were mostly mesoporous. Mesoporous MOFs can greatly increase the pore utilization rate and accelerate mass transfer relative to microporous MOFs. ${ }^{8-11}$

$\mathrm{XRD}$ (Fig. S1 in the ESI $\dagger$ ) and thermogravimetric analysis (Fig. S2 $\dagger$ ) revealed that UiO-66- $\mathrm{NH}_{2} @$ RAMIP@BSA had good chemical and thermal stability, and could meet the needs of practical applications.

\subsection{Protein exclusion efficiency of UiO-66- NH2@RAMIP@BSA}

Protein adsorption on the different materials was estimated by injecting a $1 \mathrm{mg} \mathrm{mL}^{-1}$ BSA solution on SPE columns packed with UiO-66- $\mathrm{NH}_{2} @ M I P, \mathrm{UiO}-66-\mathrm{NH}_{2} @ \mathrm{RAMIP}, \mathrm{UiO}-66-\mathrm{NH}_{2}$ @RAMIP@BSA and the corresponding non-imprinted particles. The recovery of BSA from the columns was used to evaluate the various protein exclusion efficiencies. Table 2 shows that the BSA recoveries of UiO-66- $\mathrm{NH}_{2} @ M I P$ and UiO-66- $\mathrm{NH}_{2} @ N I P$ without grafting poly (GMA) and introducing the BSA layer were just $36.5 \%$ and $37.2 \%$, respectively, while that of UiO-66$\mathrm{NH}_{2}$ @RAMIP@BSA and UiO-66- $\mathrm{NH}_{2} @$ @ANIP@BSA were 99.4\% and $99.2 \%$, respectively. The latter were much higher than those of UiO-66- $\mathrm{NH}_{2} @$ RAMIP (96.0\%) and UiO-66- $\mathrm{NH}_{2} @$ @ANIP (95.6\%). Hence, further cross-linking of BSA on the UiO-66$\mathrm{NH}_{2}$ @RAMIP surface could increase the hydrophilicity of the RAMIP materials. The formation of the hydrophilic bilayer by grafting poly (GMA) chains, and after introducing BSA on the UiO-66- $\mathrm{NH}_{2}$ surface, resulted in excellent protein exclusion

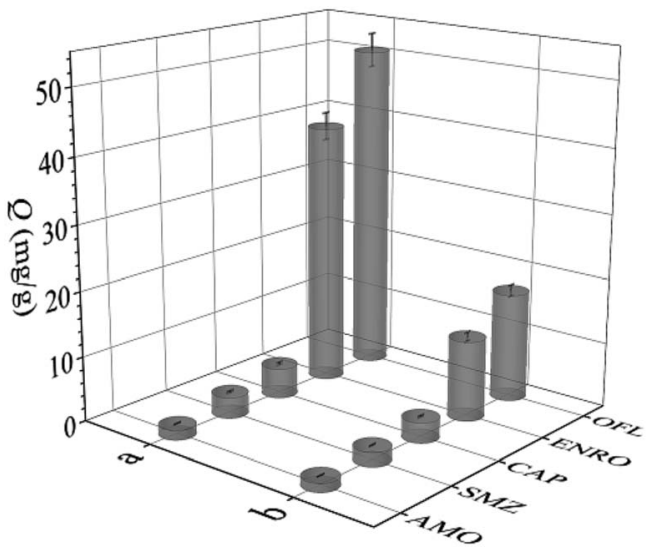

Fig. 6 Adsorption capacity of OFL, ENRO, CAP, SMZ and AMO on (a) UiO-66- $\mathrm{NH}_{2}$ @RAMIP@BSA and (b) UiO-66- $\mathrm{NH}_{2}$ @RANIP@BSA.

efficiency. Therefore, UiO-66- $\mathrm{NH}_{2} @$ QRAMIP@BSA was the most suitable SPE material for pre-treating biological samples.

\subsection{Absorption capacity and kinetics}

The adsorption capacities of UiO-66- $\mathrm{NH}_{2} @$ RAMIP@BSA and UiO-66- $\mathrm{NH}_{2} @ \mathrm{RANIP@BSA} \mathrm{were} \mathrm{initially} \mathrm{determined} \mathrm{with}$ adsorption isotherms. As shown in Fig. 5A, the adsorption capacities were enhanced with increasing standard solution concentration over the range $100-1300 \mathrm{mg} \mathrm{L}^{-1}$, and reached saturation at $50.55 \mathrm{mg} \mathrm{g}^{-1}$ and $16.40 \mathrm{mg} \mathrm{g}^{-1}$, respectively. The adsorption capacity of UiO-66- $\mathrm{NH}_{2} @$ RAMIP@BSA was much larger than that of UiO-66- $\mathrm{NH}_{2} @$ RANIP@BSA. Compared with reported MIP absorbents, $Q_{\max }$ for UiO-66- $\mathrm{NH}_{2} @ \mathrm{RAMIP} @ B S A$ was higher than that of absorbents using silica and polymer resin, ${ }^{19-27}$ indicating that the UiO-66- $\mathrm{NH}_{2} @ \mathrm{RAMIP@BSA}$ composites exhibited efficient extraction and could have wide analysis applications. The adsorption rate of UiO-66-

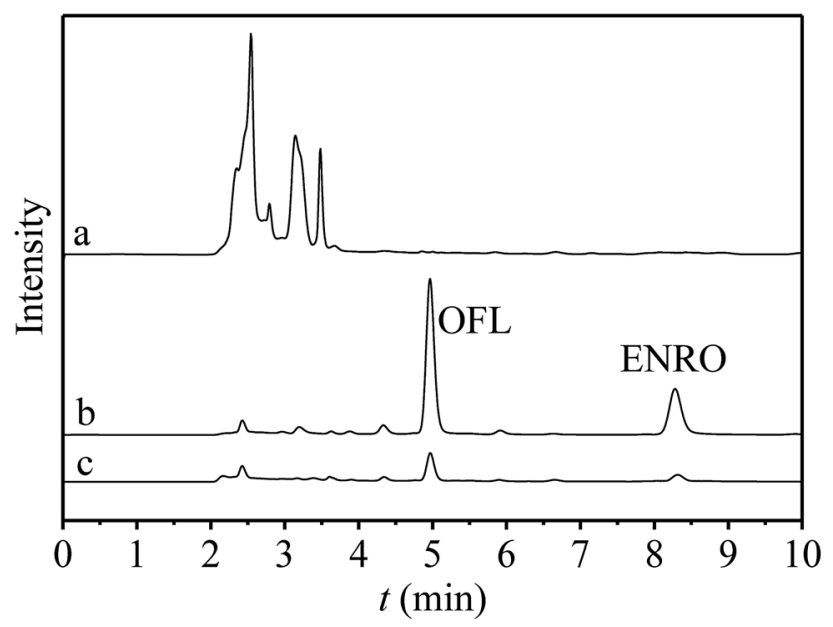

Fig. 7 The chromatograms of (a) the blank bovine serum, (b) the elution of UiO-66- $\mathrm{NH}_{2}$ @RAMIP@BSA after treatment of spiked bovine serum and (c) the elution of UiO-66- $\mathrm{NH}_{2}$ @RANIP@BSA after treatment of spiked bovine serum. 
Table 3 Recoveries of OFL and ENRO obtained from spiked bovine serum

\begin{tabular}{|c|c|c|c|c|c|c|c|}
\hline \multirow[b]{2}{*}{ Analytes } & \multirow[b]{2}{*}{ Materials } & \multicolumn{2}{|l|}{$0.5 \mu \mathrm{g} \mathrm{mL} L^{-1}$} & \multicolumn{2}{|l|}{$5 \mu \mathrm{g} \mathrm{mL}^{-1}$} & \multicolumn{2}{|l|}{$50 \mu \mathrm{g} \mathrm{mL}{ }^{-1}$} \\
\hline & & Recovery (\%) & RSD (\%) & Recovery (\%) & RSD (\%) & Recovery (\%) & RSD (\%) \\
\hline OFL & 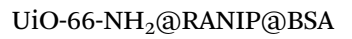 & 31.2 & 4.1 & 33.4 & 3.3 & 36.5 & 2.3 \\
\hline \multirow[t]{2}{*}{ ENRO } & 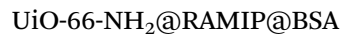 & 95.5 & 4.0 & 94.1 & 4.1 & 102.6 & 3.4 \\
\hline & UiO-66-NH & 30.8 & 3.8 & 32.5 & 2.9 & 35.7 & 4.4 \\
\hline
\end{tabular}

$\mathrm{NH}_{2} @$ RAMIP@BSA was investigated. In Fig. 5B, adsorption equilibrium was reached in $9 \mathrm{~min}$, which was much faster than that of MIPs prepared by traditional polymerization methods and other imprinting materials. This was because of the uses of mesoporous MOF substrate. Recently, a RAMIP was prepared using $2 \mu \mathrm{m}$ spherical silica gel and atom-transfer radical polymerization. ${ }^{28}$ Although this material has some advantages in adsorption capacity and limits of detection, UiO-66- $\mathrm{NH}_{2}$ @RAMIP@BSA has a better adsorption rate, protein exclusion efficiency, and recovery.

The results of the Langmuir, Freundlich, and LangmuirFreundlich fits are shown in Table S1. $\dagger$ By comparing the $R^{2}$ values, it could be concluded that the adsorption of OFL on UiO66- $\mathrm{NH}_{2} @ \mathrm{RAMIP@BSA} \mathrm{and} \mathrm{UiO-66-} \mathrm{NH}_{2} @ \mathrm{RANIP@BSA} \mathrm{corre-}$ sponded to the Langmuir-Freundlich model. From the fitting results, the theoretical value of $Q_{\mathrm{m}}$ from that model was closer to the measured value. The $K_{\mathrm{L}}$ value of UiO-66- $\mathrm{NH}_{2}$ @RAMIP@BSA was much larger than that of UiO-66- $\mathrm{NH}_{2}$ @RANIP@BSA, which indicated that UiO-66- $\mathrm{NH}_{2} @ \mathrm{RAMIP@BSA}$ was more attractive to OFL. At the same time, the $m$ value of UiO-66- $\mathrm{NH}_{2} @$ RANIP@BSA was close to 1, which indicated that its adsorption sites were more uniform because they all involved physical adsorption. The higher $m$ value for $\mathrm{UiO}-66-\mathrm{NH}_{2}$ @RAMIP@BSA indicated nonuniform adsorption sites that involved both nonspecific physical adsorption and specific chemical adsorption.

The kinetics fits are shown in Table $\mathrm{S} 2 . \dagger$ From the $R^{2}$ values, it could be concluded that adsorption on UiO-66- $\mathrm{NH}_{2}$ @RAMIP@BSA correlated with pseudo second-order kinetics. The fitting results showed that its adsorption rate was determined by the square of the number of unoccupied imprinted surface sites, and the mechanism was chemical adsorption, which involves electronic bonding between the adsorbent and the adsorbate. This result also confirmed the theoretical analysis of Section 3.1.

\subsection{Adsorption selectivity of UiO-66- $\mathrm{NH}_{2} @ \mathrm{RAMIP@BSA}$}

The selectivity of UiO-66- $\mathrm{NH}_{2} @$ RAMIP@BSA was compared with that of UiO-66- $\mathrm{NH}_{2} @$ RANIP@BSA. The three commonly used antibiotics AMO, SMZ, and CAP, and the structural analogue ENRO of OFL, were used to investigate adsorption selectivity, as shown in Fig. 6. The IF values for OFL, ENRO, AMO, SMZ, and CAP were 3.00, 3.25, 1.14, 1.50, and 1.50, and its SC were 1.26, 33.48, 15.70, and 10.87, respectively. The molecular sizes increased in the order SMZ, CAP, OFL $\approx \mathrm{ENRO}$, and
AMO. Because the molecular size and structure of the analogue ENRO were the most similar to those of OFL, its adsorption capacity was higher relative to those of SMZ, AMO, and CAP. The molecular mass of CAP was similar to that of OFL, but its structure was different, so its adsorption capacity decreased greatly. The size of SMZ was smaller than that of CAP, so its adsorption capacity was lower than that of CAP. The size of AMO was the largest; therefore, it had the lowest adsorption capacity because of less physical adsorption, which led to the minimum IF. Thus, UiO-66- $\mathrm{NH}_{2} @$ QRAMIP@BSA had high selectivity and could recognize OFL and ENRO in the presence of other commonly used antibiotics.

\subsection{Enrichment and separation of OFL and ENRO in bovine serum by the UiO-66- $\mathrm{NH}_{2} @$ QRAMIP@BSA}

Under the optimized conditions, UiO-66- $\mathrm{NH}_{2} @ \mathrm{RAMIP@BSA}$ was used to selectively extract OFL and ENRO from bovine serum samples via RP-HPLC. Chromatograms of bovine serum samples are shown in Fig. 7. None of the target compounds were detected in the bovine serum samples (curve a), while OFL and ENRO could be detected after enrichment by using UiO-66$\mathrm{NH}_{2} @ R A M I P @ B S A$ (curve b) and the non-imprinted materials (curve c). The method is illustrated in Table 3. Specifically, the determinations were evaluated by using bovine serum samples spiked with OFL and ENRO at concentrations of $0.5,5$, and 50 $\mu \mathrm{g} \mathrm{mL}$; the recoveries of OFL and ENRO were 93.7-104.2\%, and the RSDs were $2.0-4.5 \%(n=3)$. The linear range and LOD were

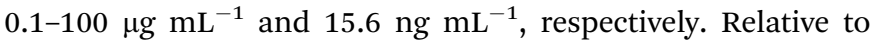
other core materials (Table $\mathrm{S} 3 \dagger$ ), UiO-66- $\mathrm{NH}_{2}$ had advantages in addition to the slightly higher LOD. In summary, the UiO-66$\mathrm{NH}_{2}$ @RAMIP@BSA could be used for highly selective enrichment and separation of OFL and ENRO in biological samples.

\section{Conclusions}

Highly hydrophilic UiO-66- $\mathrm{NH}_{2} @$ RAMIP@BSA was prepared, and its protein exclusion rate was $99.4 \%$. Its adsorption capacity was as high as $50.55 \mathrm{mg} \mathrm{g}^{-1}$, and the adsorption could reach equilibrium within 9 min. Combined with RP-HPLC, it was successfully used to separate and detect OFL and ENRO in bovine serum. The recoveries were $93.7-104.2 \%$ and the RSDs were $2.0-4.5 \%$. The detection limit was $15.6 \mathrm{ng} \mathrm{mL} \mathrm{m}^{-1}$ and the linear range was $0.1-100 \mu \mathrm{g} \mathrm{mL}^{-1}$. Compared with previous reports, the performance of this material was much better, 
which greatly simplifies pretreatment steps of biological samples and improves the analysis efficiency.

\section{Conflicts of interest}

The author(s) declare that they have no competing interests.

\section{Acknowledgements}

This work was financially supported by the National Natural Science Foundation of China (No. 21565001) and the Key Research and Development Program of Ningxia (Special Project for Foreign Cooperation) (2019BFH02004).

\section{References}

1 H. D. de Faria, L. C. D. Abrao, M. G. Santos, A. F. Barbosa and E. C. Figueiredo, Anal. Chim. Acta, 2017, 959, 43-65.

2 M. Niu, C. Pham-Huy and H. He, Microchim. Acta, 2016, 183, 2677-2695.

3 S. Pardeshi and S. K. Singh, RSC Adv., 2016, 6, 23525-23536. 4 H. Xie, W. Ji, D. Liu, W. Liu, D. Wang, R. Lv and X. Wang, RSC Adv., 2015, 5, 48885-48892.

5 Y. Lv, J. Zhang, M. Li, S. Zhou, X. Ren and J. Wang, Anal. Methods, 2016, 8, 3982-3989.

6 W. Xu, S. Su, P. Jiang, H. Wang, X. Dong and M. Zhang, J. Chromatogr. A, 2010, 1217, 7198-7207.

7 G. Férey, Chem. Soc. Rev., 2008, 37, 191-214.

8 K. Qian, G. Fang and S. Wang, Chem. Commun., 2011, 47, 10118-10120.

9 Z. Iskierko, P. S. Sharma, D. Prochowicz, K. Fronc, F. D’Souza, D. Toczydłowska, F. Stefaniak and K. Noworyta, ACS Appl. Mater. Interfaces, 2016, 8, 19860-19865.

10 A. Asfaram, M. Ghaedi and K. Dashtian, Ultrason. Sonochem., 2017, 34, 561-570.

11 H. Liu, L. Mu, X. Chen, J. Wang, S. Wang and B. Sun, J. Agric. Food Chem., 2017, 65, 986-992.
12 J. B. Decoste, G. W. Peterson, B. J. Schindler, K. L. Killops, M. A. Browe and J. J. Mahle, J. Mater. Chem. A, 2013, 1, 11922-11932.

13 H. Molavi, A. Eskandari, A. Shojaei and S. A. Mousavi, Microporous Mesoporous Mater., 2018, 257, 193-201.

14 M. Kandiah, M. H. Nilsen, S. Usseglio, S. Jakobsen, U. Olsbye, M. Tilset, C. Larabi, E. A. Quadrelli, F. Bonino and K. P. Lillerud, Chem. Mater., 2010, 22, 6632-6640.

15 H. Wu, T. Yildirim and W. Zhou, J. Phys. Chem. Lett., 2013, 4, 925-930.

16 J. B. DeCoste, J. A. Rossin and G. W. Peterson, Chem.-Eur. J., 2015, 21, 18029-18032.

17 Y. H. Yang, L. T. Liu, M. J. Chen, S. Liu, C. B. Gong, Y. B. Wei, C. F. Chow and Q. Tang, Mater. Sci. Eng., C, 2018, 92, 365373.

18 Z. Wang, T. Qiu, L. Guo, J. Ye, L. He and X. Li, React. Funct. Polym., 2018, 126, 1-8.

19 Z. H. Hu, Y. F. Wang, A. M. Omer and X. K. Ouyang, Int. J. Biol. Macromol., 2018, 107, 453-462.

20 Y. He, Y. Huang, Y. Jin, X. Liu, G. Liu and R. Zhao, ACS Appl. Mater. Interfaces, 2014, 6, 9634-9642.

21 J. Zhang, L. L. Wang, J. Q. Ma and Y. L. Wang, Food. Anal. Methods, 2014, 7, 721-729.

22 H. B. He, C. Dong, B. Li, J. P. Dong, T. Y. Bo, T. L. Wang, Q. W. Yu and Y. Q. Feng, J. Chromatogr. A, 2014, 1361, 23-33.

23 X. Guan, T. Cheng, S. Wang, X. Liu and H. Zhang, Anal. Bioanal. Chem., 2017, 409, 3127-3133.

24 Y. F. Wang, H. X. Jin, Y. G. Wang, L. Y. Yang, X. K. OuYang and W. J. Wu, Molecules, 2016, 21, 915.

25 T. Zhao, X. Guan, W. Tang, Y. Ma and H. Zhang, Anal. Chim. Acta, 2015, 853, 668-675.

26 H. Yan and F. Qiao, J. Liq. Chromatogr. Relat. Technol., 2014, 37, 1237-1248.

27 H. Wang, R. Wang and Y. Han, J. Chromatogr. B: Anal. Technol. Biomed. Life Sci., 2014, 949-950, 24-29.

28 J. Li, L. Zhao, C. Wei, Z. Sun, S. Zhao, T. Cai and B. Gong, J. Sep. Sci., 2019, 42, 2491-2499. 